WORKING PAPER IN IDEOLOGY IN DISCOURSE ANALYSIS

No. 23 (July 2008)

\title{
Ideological Fantasy at Work ${ }^{1}$
}

\author{
Dr Jason Glynos \\ Department of Government \\ University of Essex \\ ljglyn@,essex.ac.uk
}

ISSN: $1758-8782$ 


\title{
Ideological Fantasy at Work ${ }^{2}$
}

\author{
Jason Glynos
}

\begin{abstract}
This paper explores the normative and ideological significance of fantasy in the context of workplace practices. I situate my approach to fantasy against the background of a 'logics approach' to social analysis, which is grounded in the poststructuralist and postmarxist genres of political theorizing. In considering a number of existing analyses of workplace practices which appeal to the category of fantasy, I focus on some studies in which fantasy can be said to play a role in sustaining workplace practices. I use this literature to draw out and formalize some basic features of the logic of fantasy, before turning my attention to a study which opens up a theoretical space for thinking about a mode of subjectivity which appears to escape the constraining logic of fantasy. Finally, using the insights gleaned from these studies, I develop an analytical framework centred around the logic of fantasy. The benefit of this framework, I claim, is that it makes clear the analytical distinction between two aspects of critique and transformation: an aspect linked to the norms of a practice and an aspect linked to the way subjects engage with those norms. Making this distinction explicit, I argue, allows us to pose interesting theoretical, critical, and methodological questions, including how these two aspects intersect in different contexts. The aim is to pluralize understandings of social and political critique and transformation, in a way which is relevant (but not necessarily tied) to workplace practices.
\end{abstract}




\section{Introduction}

It may seem odd to link fantasy with work. It appears difficult to imagine how the 'irreality' of fantasy can have anything serious to contribute to our understanding of the 'reality' of work. Yet most people's experiences point to the power of fantasies to structure the motivations underpinning much economic practice, production practices included. This paper takes seriously this intuition. I draw on work that is inspired by hermeneutics, post-marxism, poststructuralism, Lacanian psychoanalysis, critical management studies and discourse analysis, to think workplace practices in terms of logics, and the logic of fantasy in particular (eg., Best and Connolly 1982; Resnick and Wolff 1987, 2005; Gibson-Graham 2006; Laclau and Mouffe 1985; Laclau 1990; Glynos and Howarth 2007; Contu and Willmott 2006). It may thus be possible to envisage a psychoanalytic contribution to the field of critical political theory and economy by examining some of the preconditions for the social and political transformation of workplace practices. ${ }^{3}$

The Lacanian concept of fantasy has already been deployed in developing a distinctive approach to the critique of ideology (Zizek 1989; Glynos 2001a; Stavrakakis 1999; Daly 1999, 2004). In this paper I develop these insights further, relating them to workplace practices. The aim is to draw out the conceptual and critical implications of a Lacanian approach to the analysis of such practices, particularly with reference to a small but significant literature that already invokes the concept of fantasy in this area. For the purpose of this paper, I will take the logic of fantasy to aim less at the content of a subject's fantasy than the mode or ethos with which a subject engages in a practice. While the specificity of this logic will be elaborated later on, it is worth pointing out that the analytical and critical value of a distinction between modes of subjectivity has been noted by a number of scholars before, finding itself expressed in multiple ways, usually in the form of oppositions such as mourning/melancholia, desire/drive, fantasy/crossing of fantasy, repression/sublimation, ressentiment/irony, symptom/identification with symptom, phallic jouissance/Other jouissance, masculine enjoyment/feminine enjoyment (eg., Brown 1996, Glynos 2001a, 2001b, Zizek 1989, Zupancic 2000, Copjec 1994: Ch. 8). In the context of workplace practices in particular, such paired modalities of subjectivity either have been or can be mapped onto the opposition capitalism/communism (eg., Ozselcuk \& Madra 2005, Madra 2006, Ozselcuk 2006) and capitalist economy/community economy (Gibson-Graham 2006). My aim in this paper is to develop this shared insight about modes of subjectivity through the (Lacanian) categories of fantasy and enjoyment by sketching a framework within which questions of ideology and politics can be usefully posed and pursued. ${ }^{4}$

My argument can be summarized as follows. Existing studies of workplace practices that invoke the category of fantasy are often underpinned by normative worries worries having to do with the perpetuation of relations of domination or exploitation, usually qualified as capitalist relations of domination and exploitation. However, the way fantasy relates to questions of normative critique tends not to be very clearly spelled out. In my view, specifying this relation in detail and with nuance is not easy. The argument - or, perhaps better, the suggestion - I want to make is that there may be benefits in keeping analytically distinct two aspects of critique: normative critique and ethical critique (Glynos \& Howarth 2007: 191-99). While normative critique takes aim at the substantive content of the norms that govern a practice, ethical 
critique takes aim at the way a subject relates to those norms - the mode or ethos of a subject's engagement. ${ }^{5}$ A normative framework, I argue, should be seen to emerge out of the dynamic interaction between the analyst's interpretive activity on the one hand and the discursive context of the workplace on the other. The ethical framework, on the other hand, takes its bearings more from the logic of fantasy: an ideological mode suggests that a subject's engagement with the norms of a practice is governed quite stringently by the logic of fantasy, while an ethical mode of suggests that a subject's engagement with the norms of a practice escapes the confines of the logic of fantasy. Finally, I argue that related, though not reducible, to the normative/ethical distinction, is an analytical distinction between two aspects of transformation. The first aspect is connected to the status of norms (rather than the content of norms): is a norm contested or not? The second aspect, however, relates again to how the subject relates to those norms: is this mode or ethos of engagement ideological or ethical? The approach advocated in this article, I believe, will help make clearer the ideological and normative aspects of social and political analysis.

To develop this argument I first situate my approach to fantasy against the background of a general logics approach to social analysis, which is grounded in the poststructuralist and postmarxist genres of political theorizing (Glynos \& Howarth 2007). I then consider a number of existing analyses of workplace practices in the literature which appeal to the category of fantasy. In order to minimize conceptual overdetermination and ambiguities, my strategy here is to narrow the focus of my inquiry to those scholars who explicitly appeal to a Lacanian understanding of psychoanalysis and fantasy. I focus first on some studies in which fantasy can be said to play a role in sustaining workplace practices. I use this literature to draw out and formalize some basic features of the logic of fantasy, as a way of contributing to the task of giving this category greater conceptual specificity. I then turn my attention to a study which opens up a theoretical space for thinking about a mode of subjectivity which does not appear to conform strictly to a logic of fantasy. I thus build on all the above insights to develop an analytical framework centred around the logic of fantasy. The benefit of this framework is that it makes clear the distinction between two aspects of critique and transformation: an aspect linked to the norms of a practice, and an aspect linked to the subject's mode of engagement with those norms. Making this distinction explicit, I argue, allows us to pose interesting theoretical, empirical, critical, and methodological questions, including how these two aspects intersect in different contexts. The aim is to pluralize understandings of social and political critique and transformation, in a way which is relevant, but not necessarily tied, to workplace practices.

\section{A Logics Approach}

A logics approach builds into its framework an explicit acknowledgement of the foundational status of the politically contestable moment in the institution of a practice. Influenced principally by Heidegger, Lacan, and Laclau \& Mouffe, but also drawing on Foucault, Wittgenstein, and Derrida, the approach is premised on the radical contingency of social relations. This axiomatic presupposition implies that any system or structure of social relations is constitutively incomplete or lacking for a subject. From this point of view, practices are governed by a dialectic defined by incomplete structures on the one hand, and the collective acts of subjective identification that sustain or change those incomplete structures on the other. ${ }^{6}$ 
The appeal to logics - and fantasmatic logics in particular - can be understood against this background, for they simply furnish a language with which to characterize and critically explain the existence, maintenance, and transformation of concrete practices. Logics seek to capture the purposes, rules and self-understandings of a practice in a way that is sensitive to key ontological presuppositions. They aim to assist not just in describing or characterizing it, but in capturing the various conditions which make that practice 'work' or 'tick', thereby contributing to our understanding of how a practice becomes possible, intelligible, and vulnerable.

Three such logics can be briefly sketched: social, political, and fantasmatic logics. In a first approach social logics can be said to help characterize practices by setting out the rules, norms, and self-understandings informing the practice. Political logics account for the historical emergence and formation of a practice by focusing on the conflicts and contestations surrounding its constitution; and fantasmatic logics help account for the way subjects are gripped by a practice. We could say, roughly, that they offer answers to the 'what', 'how', and 'why' questions. If social logics assist in the task of directly characterizing practices along a synchronic axis (the 'what'), then political logics can be said to focus more on the diachronic aspects of a practice, thus explicating the way they have emerged, or are contested and/or transformed (the 'how'). Political logics aim to capture those processes of collective mobilization precipitated by the emergence of the political dimension of social relations, involving the construction, defence, and naturalization of new frontiers. But they also pertain to processes which seek to interrupt or break up this process of drawing frontiers. Political logics thus emphasize the dynamic process by which political frontiers are constructed, stabilized, strengthened, or weakened and disarticulated. ${ }^{7}$

Fantasmatic logics add a further explanatory and critical layer to the process of accounting for change or continuity. If political logics provide a politically-inflected signifying frame within which to show how social practices come into being or are transformed, then fantasmatic logics provide the means to understand why specific practices and regimes grip subjects. To use terms from a different though related context, if political logics concern signifying operations, fantasmatic logics concern the force behind those operations (Laclau 2005:101). Fantasmatic logics thus contribute to our understanding of the resistance to change of social practices (the 'inertia' of social practices), but also the speed and direction of change when it does happen (the 'vector' of political practices).

In the remaining part of this section I sketch the main parameters of social logics, political logics, and what has been termed 'counter-logics' (Glynos \& Howarth 2007: 193-7), in order to better contextualize the role of fantasmatic logics and to pre-empt my attempt later to highlight the social and political significance of fantasy. This is done by reinterpreting aspects of Gibson-Graham's work using the grammar of logics, specifically their case study of the Latrobe Valley and their general discussion of what they refer to as 'capitalocentrism'. Gibson-Graham's work is especially conducive to this exercise because they explicitly adopt a post-structuralist approach to their study of the economy.

The Latrobe Valley case study focused on workers in the electricity and coal mining industries in Victoria State, SE Australia, close to Melbourne. The case explored how 
workers were coping in the wake of mass unemployment following retrenchment of these industries and privatization of the State Electricity Commission of Victoria (SEC) in the 1990s. In it, Gibson-Graham point to what I would characterize as the discursive context and political logics at play in the institution of SEC in the early 1920s. A range of discourses furnished the elements with which to justify not simply the need to establish an independent energy source for Melbourne but also the need to locate the power station in the Latrobe Valley. These discourses included the increasingly hegemonic economic science of numbers, and a regional discourse of economic growth, self-sufficiency, and individual well-being. Individual state officials and other key figures were able to use these discourses to draw frontiers (eg., between Victoria and other Australian states) and thus persuade Victoria's state government and people to set up SEC as a way of establishing Melbourne's independence energy supply-wise from other Australian states. One can speculate here about how the political logics informing these practices acquired their force with reference to a series of intersecting fantasmatic logics, entailing the appeal to individual desires linked to the prospect of higher standards of living, as well as the appeal to potential obstacles to the realization of such desires, such as the inability of other states (whether through inefficiency or incompetence) to satisfy Melbourne's energy needs (Gibson-Graham 2006: 27-41).

With the establishment and early success of SEC came the institution of new work and life practices whose norms were quickly sedimented in a set of social logics. The practices can be characterized in terms of a social logic of paternalism, insofar as employees tended to rely upon and defer excessively to SEC. (SEC's presence extended well beyond the workplace to include all aspects of town and domestic life, since it provided a whole range of services to the general public, such as responding to electricity, plumbing, and other calls). Social logics of individual consumption and competition also predominated. Such logics implied a tendency in the selfinterpretations of individual workers in the Latrobe Valley to see themselves in competition (prestige- and resource-wise) with workers in other towns of the Latrobe Valley, as well as with workers outside the Latrobe Valley (Gibson-Graham 2006: 419). A brief and unsuccessful attempt to contest these norms and social logics in 1947 meant that continued SEC growth helped sustain these practices and identities for many decades. In fact, it was precisely 'the loss of this strong personal and collective identity and the sense of inclusion in a project that has been most devastating' in the wake of the dislocations suffered by SEC workers in the 1990s (Gibson-Graham 2006: 39).

How then might fantasmatic logics and counter-logics contribute to this explanatory narrative? Though the category of fantasy will be discussed in more detail in the next section, we can mention briefly here how in their interviews with workers GibsonGraham found not just ressentiment and anger directed at those state leaders under whose watch these dislocatory events took place, but also self-directed guilt and anger for allowing themselves to be lulled into a state of complacency and complicity. These responses to the events reveal a set of possible dependency fantasies which sustained social practices governed by the social logics identified (fantasies to be cared for and pampered, as if by a parent, and to be protected from threats to this way of life). 
Such fantasies may serve to structure many responses to the dislocatory events of the 1990 s, whether by projecting one's personal vulnerability onto someone else (state authorities or SEC management or other SEC workers) who can serve as an external receptacle of blame, or by turning one's blame onto oneself in an overwhelming and crippling way. Strongly held fantasies thus tend to provide rigid templates with which to 'read' events, pushing aside all ambiguity and ambivalence which may enable alternative readings. Yet Gibson-Graham did find glimpses of alternative 'becomings' as a result of these dislocations:

By listening for expressions of 'fugitive energies' and emotions that exceed the fund of subjectivities institutionally provided and 'assumed' in the valley, we have identified care for the other, concerns for justice and equity in and for the region, and calls for new practices of community as potentialities that have arisen out of subjection.

(Gibson-Graham 2006: 51)

Elsewhere the term 'counter-logics' has been invoked to capture precisely those 'potentialities' that reside in the interstices of dominant practices and discourses (Glynos \& Howarth 2007: 193-7). Counter-logics become visible in those moments when articulations in the self-interpretations of subjects resist easy assimilation into an already existing mould - the view, for example, that the regional economy should be defined primarily in terms of its energy resources or its economic growth. Following Connolly (1999: 146), Gibson-Graham suggest that 'without an active politics of becoming, such potentialities can easily become reintegrated into old discourses..., rather than directed toward new ways of being' (Gibson-Graham 2006: $51)$.

These observations concerning counter-logics and their relation to dominant social logics are important when critically analysing workplace practices, specifically as regards the methodological issue of how to conceptualize the process of identifying and naming logics. One way of seeing this is to refer to Gibson-Graham's discussion and treatment of political economy. In the domain of political economy GibsonGraham regard what they call 'capitalocentrism' as occupying a hegemonic position. In this view, capitalocentric social logics describe articulations which, in subjects' self-interpretations, distribute 'positive value to those activities associated with capitalist economic activity however defined', and assign 'lesser value to all other processes of producing and distributing goods and services by identifying them in relation to capitalism as the same as, the opposite of, a complement to, or contained within' (Gibson-Graham 2006: 56). In my terms, Gibson-Graham seek to sensitize themselves, as analysts, to the possible counter-logics inhering in the interstices of the dominant social logics of capitalocentrism. In their words, their efforts are 'aimed at fostering conditions under which images and enactments of economic diversity (including noncapitalism) might stop circulating around capitalism, stop being evaluated with respect to capitalism, and stop being seen as deviant or exotic or eccentric departures from the norm' (Gibson-Graham 2006: 56). They see this as a project of 'reading the economy for difference rather than dominance' (GibsonGraham 2006: 59). For example, certain feminist 'readings for difference' point to 'the interdependence of household, community, and market-based economic activities', informal economy 'readings for difference' point out how 'livelihoods are sustained by a plethora of economic activities that do not take the form of wage 
labour, commodity production for a market, or capitalist enterprise', and certain Marxist 'readings for difference' focus on 'the relations between producers and nonproducers' (Gibson-Graham 2006: 57-9).

Capitalocentrism, conceived as a dominant social logic, registers the tendency to read all that one encounters as variations of, or departures from, its own image, instead of being open to more diverse readings which tap into counter-logics, or what Connolly calls 'fugitive energies of becoming' (Connolly 2002: 48). Commodifying processes, for example, often function collectively as a powerful totalizing tendency. But this should be seen as no more than a dominant social logic buoyed up by the subjects participating in these practices and thus subject to potential contestation and complexification. In the domain of child-care, for example, instead of reading associated activities as subsumable under a general commodification tendency, Gibson-Graham seek to identify other potentialities residing in existing child care practices. The role of counter-logics is crucial here, for in this case counter-logics can refer to those dynamics that capture 'the continued generation and regeneration of forms of child care in which market mechanisms play no dominant role' (GibsonGraham 2006: 74).

The centrality of judgement in the analyst's task of identifying and naming social logics and counter-logics is hard to ignore here, and can be further illustrated with reference to Gibson-Graham's child care example:

[T]he work of parents setting up a baby-sitting club might rarely be seen as a form of economic activism, especially as this organization could include people from very different income and occupational groups who identify differently with one or more of... the subject positions [of consumer, worker, selfemployed, unemployed, capitalist entrepreneur, investor, and so on]. Yet... this act of recognizing and creating interdependence can be an important contribution to a counterhegemonic politics of strengthening the community economy.

(Gibson-Graham 2006: 77; emphasis added)

The active role of the researcher in studying work and workplace practices is highlighted also by Best and Connolly (1982: 117-121):

[I]n the absence of available examples or theories of work that challenge the dominant work ethic and work system, the worker has no alternative conception against which to appraise his condition. Even a slave would say he is happy if his experience were so constricted that he believed slavery to be a natural and necessary condition for people like him. The worker's experience is not so thoroughly limited, but in modern capitalist society his experience with alternative forms of work has been severely restricted.

(Best and Connolly 1982: 121)

Whether we look at an economic practice from the point of view of how products are exchanged, how they are produced, or how they are appropriated and distributed, a whole host of possibilities opens up which it is not necessary to force into one (capitalocentric) mould comprising market transactions, wage labour, and private 
shareholding enterprises. Alternative market and nonmarket forms of transaction would thus come into view, as would alternative forms of labour, and alternative capitalist and noncapitalist organizational forms of appropriation and distribution (Gibson-Graham 2006: 73). From the point of view of exchange, hour-based (as opposed to money-based) baby-sitting clubs, underground cash-in-hand arrangements, and various forms of barter exchange comprise alternative market forms of transaction, while parents sharing child care and offers by family and friends to babysit for free (as a gift) comprise non-market forms of transaction. From the point of view of production, alternative forms of paid labour can be observed in relation to child-care cooperative workers, au pairs paid in cash and kind, or live-in students paid in terms of room and board; and non-paid forms of labour can be observed in child care offered by parents and extended family, or volunteered child care by friends, neighbours, churches, and other organizations. Finally, from the point of view of the organizational form, alternative capitalist forms include those child-care enterprises that subscribe to one or more of an environmental or social ethic (ie., in addition to making a profit), and non-capitalist forms of organization include informal household child-care arrangements, child-care cooperatives, and various state and nonprofit enterprises.

For Gibson-Graham this process of 'reading for difference' entails disarticulating elements from a dominant capitalocentric reading of various practices, the organizational form, or the individual economic subject, and rearticulating them as part of a more diverse and plural economy (Gibson-Graham 2006: 72-7). Community economy thus functions for Gibson-Graham as an overarching counter-logic to the dominant social logic of capitalocentrism (Gibson-Graham 2006: 77-8). For them ' $[\mathrm{m}]$ omentary eruptions that break familiar patterns of feeling and behaviour offer glimmers of possibility' for a more plural and diverse economy (Gibson-Graham 2006: 51; see also 192-6). Along similar lines, Best and Connolly seek to create conditions under which work is understood not merely in instrumental terms (something done only as a means to other things, for example only for pay), but as something that 'is done partly for pay, partly because of the intrinsic interest of the work, partly because of a desire to create socially useful products, and partly because of a desire to gain the respect of others through the social contribution one makes' (Best and Connolly 1982: 129). ${ }^{8}$

In this section I have sought to contextualize fantasmatic logics in relation to social and political logics and counter-logics. I have not yet discussed in detail the role fantasmatic logics play in accounting for the way social practices tend to make difficult the public contestation of dominant norms, and for the energy that drives many political projects. My claim here is that there is much to be gained in trying to make these sorts of logics more explicit. In this view, social structures are seen as norm-governed practices buoyed up by subjects who, in turn, are sustained by their self-interpretations and fantasies. In the following sections I sketch out the way that fantasy can be invoked in thinking about subjects' relations to workplace practices in order to suggest that the political economy of work should be understood as a discursive construction which is fantasmatically motivated and sustained. In the first case I look at instances in which fantasies appear to sustain workplace practices in an ideologically-complicitous way. In the second case I consider how we might conceptualize alternative relations between fantasy and workplace practice. In so 
doing I hope to flesh out the logic of fantasy, including its political and ideological significance, in greater theoretical detail.

\section{How Fantasies Sustain}

There is a small but significant literature which explores workplace practices from the point of view of fantasies (eg., Walkerdine 2006, 2005; Gabriel 1997, 1995; Contu and Willmott 2006; Willmott 2007; Byrne and Healy 2006). One study, for example, finds a good portion of fantasies structuring workplace practices to be leadership fantasies, namely, individuals' fantasies about their organizational superiors: the caring leader, the accessible leader, the omnipotent leader, and so on (Gabriel 1997). Another study charts a wider range of fantasmatic contents in the context of workplace practices (Walkerdine 2005). For example, one woman's excessive work rate, welcomed and solicited by her boss, is accounted for by appealing to a fantasy in which her efforts would one day be rewarded by the long sought-after recognition of her father. Individual fantasies here are understood to downplay the significance of poor pay and conditions, insecurity and exploitation, including the broader sociocultural and politico-economic conditions which make these possible. Such studies are significant because they represent initial attempts to document the content of individuals' workplace fantasies, trading on the powerful intuition that they have an important role to play in our understanding of how social practices - in this case workplace practices - are organized, sustained, or potentially transformed. They make some interesting observations and generate some useful critical insights. In my view, it is possible to build on these insights by linking them more explicitly and systematically to the question of ideology, thereby making the political and normative significance of fantasy clearer. In order to see this I offer an initial sketch of the logic of fantasy. I then use empirical material from existing literature to illustrate this logic. My strategy here is to narrow the focus of my inquiry to those scholars who explicitly appeal to a Lacanian understanding of psychoanalysis and fantasy - primarily to minimize conceptual overdetermination and ambiguities. I then make more explicit the connection of fantasy to questions of ideology and normative critique.

In a first approach we could say that the logic of fantasy names a narrative structure involving some reference to an idealized scenario promising an imaginary fullness or wholeness (the beatific side of fantasy) and, by implication, a disaster scenario (the horrific side of fantasy). This narrative structure will have a range of features which will vary from context to context, of course, but one crucial element is the obstacle preventing the realization of one's fantasmatic desire. In Lacanian psychoanalysis, realizing one's fantasy is impossible because the subject (as a subject of desire) survives only insofar as its desire remains unsatisfied. But the obstacle, which often comes in the form of a prohibition or a threatening Other, transforms this impossibility into a 'mere difficulty', thus creating the impression that its realization is at least potentially possible. Fantasy, therefore, is not merely a narrative with its potentially infinite variations at the level of content, although it is of course this too. It also has a certain logic in which the subject's very being is implicated: the disruption or dissolution of the logic leads to what Lacan calls the aphanisis, or vanishing, of the subject (as a subject of desire). In sum, the logic of a fantasmatic narrative is such that it structures the subject's desire by presenting it with an ideal as well as an impediment to the realization of that ideal. 
In the remainder of this section I focus on the way the logic of fantasy sustains particular work relations and patterns. Fantasies supported by the prospect of big profits, generous pay packets, career advancement, consumption of prize commodities, and hobbies, are an obvious way to think about how patterns of work are affected and sustained by fantasies. But such fantasmatically-structured desires shape the nature and content of demands made by workers and by management, as well as the way they are responded to. But in what way, more specifically, does fantasy sustain the existing political economy of work? One way of thinking about this is in relation to the political dimension of social relations. Insofar as fantasies prevent or make difficult the politicization of existing social relations, relations of subordination inclusive, one can say that fantasy helps reinforce the status quo. The logic of fantasy, then, can be construed as a narrative affirmed by workers, often unconsciously, preventing the contestation of normatively suspect social norms, and making less visible possible counter-logics.

To begin, consider Hugh Willmott's reinterpretation of a study by Brown and Humphreys of a new further education college following the merger of two former colleges (Brown and Humphreys 2006). In his reading of their study, Willmott finds both nostalgic fantasies of the past, as well as wishful fantasies projected onto the future (Willmott 2007). According to Willmott, in this newly constituted college, called Alpha College, the obstacle preventing the realization of particular desires is key to understanding the function and significance of these fantasies.

Each member of the new staff belonged to one of three groups: ex-Beta employees (these are the new college staff that come from Beta college), ex-Gamma employees (these are the new college staff that came from Gamma college), and the new senior management team. But interviews with staff members revealed how each group became an element of narrative condensation for the others' fears and anxieties, serving as key talking points around which they could each consolidate their respective identities. Ex-Beta staff and ex-Gamma staff regarded the senior management team as incompetent; but they also regarded each other with suspicion and resentment. Precisely because these scapegoating fantasies enabled the construction of a common identity which offered an informal and convenient receptacle for, or displacement of, their distinct grievances, it also suppressed an alternative, equivalential articulation of grievances and the kind of cross-group collective mobilization that this may have made possible.

While Brown and Humphreys emphasize how employees' interactions tended to consolidate their differential and oppositional identities with respect to each other, Willmott points to alternative norms and possibilities present, but not emphasized, in the interview extracts presented. For example, both ex-Beta and ex-Gamma staff invariably evoked norms linked to educational and pedagogic ideals, which appeared to them to have been eclipsed by the dominant social logic of business efficiency and productivity. Alpha College was increasingly sedimented in the mould of a business. Contesting this norm in the name of an alternative educational norm may have served as a way to mobilize support across groups. The suggestion here is that such unofficial and collective grumblings were underpinned by scapegoating fantasies; and that because they offered individual groups a modicum of relief (or enjoyment in 
Lacanian terms), they were not easily jettisoned in favour of alternative pathways, more political pathways for example.

In a similar vein, Contu and Willmott (2006) use Julian Orr's ethnographic study Talking about Machines (1996) to explore the role of fantasies informing workplace practices at the Xerox corporation. Orr emphasizes the centrality of concrete practice in understanding the development and sustenance of workers' relations and actions. Criticizing those who rely on abstract job descriptions to get a picture of this, Orr foregrounds how concrete employment relations and work practices are instrumental in shaping workers' identity. More specifically, he shows how in practice the work of photocopy repair technicians involved the construction of hero narratives, and how this process had a crucial role to play in developing their skills, and in organizing and sustaining their work and identity. Contu and Willmott seek to develop this insight by investing these narratives with fantasmatic and critical significance because they see them as integral to the reproduction of (capitalist) relations of domination.

In this study Orr found repair technicians relaying their knowledge to one another in the form of 'war stories'. These were stories describing how individual workers would bypass and thus transgress management's explicit service documentation and diagnostic procedures, but in doing so ended up repairing copiers with greater efficiency and at a much higher success rate than would have been the case had they obeyed management directly. Such stories of mastery served to consolidate the technicians' group identity by providing them with an opportunity to derive recognition and competitive kudos from them and to partake in comradely exchanges. But perhaps this enjoyment was especially poignant and binding because such war stories of heroic and masterful exploits were narrated against the background knowledge of their collective transgression of managements' public-official rules. ${ }^{9}$ As Zizek puts it,

[w] hat 'holds together' a community most deeply is not so much identification with the Law that regulates the community's 'normal' everyday circuit, but rather identification with a specific form of transgression of the Law, of the Law's suspension (in psychoanalytic terms, with a specific form of enjoyment).

(Zizek 1994: 55)

Moroever, while Orr is willing to characterize the misbehaviour of repair technicians as slightly subversive, Contu and Willmott point out how such ostensibly subversive activity ends up serving the corporation's bottom line better than would have been possible by simply following management's directives. It is in this way that the fantasy of heroic mastery underpinning workers' collective enjoyment and identity structures their work practices. When an object (here the copier machine) is invested with properties that far exceed its concrete materiality - when for instance the machine appearing in their stories becomes 'recalcitrant, annoying, fascinating and whimsical', as well as 'potentially humiliating' - it serves as the object 'through which the technicians live out the fantasy of heroism, freedom, and autonomy by battling to control its performance' (Contu and Willmott 2006: 9).

What the above illustrations have in common is the idea that fantasies can work in such a way as to sustain workplace practices. This is an insight I wish to build on in 
the remainder of this paper, especially because I feel it is possible to make more nuanced the claim - sometimes made in such studies - that fantasies play a role not just in sustaining workplace practices generally, but also in sustaining relations of domination or exploitation more specifically. In my view, there are both ideological and normative aspects at play here, and that these aspects are often conflated. My sense is that it is useful, from a critical point of view, to treat these aspects as analytically distinct where possible. In concluding this section I will say something about the ideological dimension of a practice before considering its connection to the normative import of a practice.

Insofar as subjects are heavily invested in fantasies in a way which avoids rather than affirms the radical contingency of social relations, I would like to suggest that this aspect of workplace practices can be characterized as ideological. It appeals to a conception of ideology which gives the notion of misrecognition an ontological rather than an epistemological value, thereby avoiding the usual pitfalls associated with appeals to 'false consciousness'. As Laclau puts it,

we can maintain the concept of ideology and the category of misrecognition only by inverting their traditional content. The ideological would not consist of the misrecogntion of a positive essence, but exactly the opposite: it would consist of the non-recognition of the precarious character of any positivity, of the impossibility of any ultimate suture. The ideological would consist of those discursive forms through which a society tries to institute itself as such on the basis of closure, of the fixation of meaning, of the non-recognition of the infinite play of differences. The ideological would be the will to 'totality' of any totalizing discourse.

The appeal to fantasmatic logics, then, contributes to the development of this concept of ideology by foregrounding the role subjectivity, desire, and enjoyment play in sustaining the impulse to 'closure'. In this (Lacanian) perspective fantasy serves to protect the subject (of desire) from the anxiety linked to a direct confrontation with the radical contingency of social relations. How best, then, to think the relation between ideology and normativity? Of course, the normative significance of the ideological dimension of fantasy is fairly straightforward at a general or abstract level. Here fantasies are understood to keep the political dimension of workplace practices at bay, thus sustaining what is - from the analyst's point of view, but also often from the workers' point of view - a relation of domination or exploitation. However, the important question is how to think in more detail the relation between ideological fantasy and normative deficit. And my view is that fantasy should be understood to sustain (normative) exploitation indirectly.

A reference to my earlier discussion on counter-logics can make this clear. The claim here is that the more subjects are invested in fantasies, the more likely they are to read all aspects of their practice in terms of that fantasmatic narrative, and the less likely they are to 'read for difference'. Counter-logics are precisely those potential alternative discursive patterns that inhere in the interstices of workplace practices that would provide a counterpoint to a dominant social logic. The subject tends to use fantasy as a way to protect itself from ambiguities, uncertainties, and other features which evoke intimations of anxiety. But it is precisely those ambiguities that open up 
possibilities for critical distance and alternative becomings. It thus becomes important to make explicit the normative framework that the researcher brings to the analysis and, through a process of articulation, to actively bring it into contact with those concrete alternatives residing in the practices themselves (Glynos \& Howarth 2007: 177-197).

This awareness generates a host of questions which are important from the point of view of analysis and critique. For example: How should one characterize the workplace practice as a function of social logics and norms? In what sense is the researcher's implied conception of exploitation related to the idea that subjects ought to exercise meaningful control over their working conditions (or some other idea)? What aspects of a concrete workplace practice appear to reflect this implicit grievance or to embody alternative normative potentialities? Finally, how do the identified fantasies operate in such a way as to make less visible to the subjects themselves both the potential grievances and potential alternative ways of structuring workplace practice?

\section{Beyond the Logic of Fantasy?}

I can summarize the discussion so far by outlining three key aspects of the logic of fantasy. First, it has a narrative structure which features, among other things, an ideal and an obstacle to its realization, and which may take a beatific or horrific form; second, it has an inherently transgressive aspect vis-a-vis officially affirmed ideals; and third, it purports to offer a foundational guarantee of sorts, in the sense that it offers the subject a degree of protection from the anxiety associated with a direct confrontation with the radical contingency of social relations. The question that arises here, of course, is whether there are modes of subjectivity beyond those embodied in the logic of fantasy. To put it in more empirical terms, if one accepts the ideological aspect of a subject's fantasmatic engagement in the context of a public institution or a capitalist firm, it is natural to ask whether economic production organized differently also yield a difference in the type of relations subjects have toward their fantasies (for example, not relying on fantasy to eschew radical contingency). This is precisely the thought guiding the research of Byrne and Healy in their ethnographic comparative study of cooperative firms (Byrne and Healy 2006). Following Resnick and Wolff's definition of a communal enterprise as one wherein the worker-producers are collectively the appropriators and distributors of surplus wealth (Resnick and Wolff 1987), Byrne and Healy investigate the workings of a range of cooperatives to see whether there is any evidence of a different sort of relation between subject and fantasy inhering in these forms of economic organization.

Byrne and Healy manage to extract some interesting insights from their interviews with cooperative partners. For example, in talking about their recruitment strategies, experienced coop members had found that in trying to hire someone who was right for this sort of work environment it was best to avoid those who saw their coop job either as 'just a job' or as an 'alternative experience'. Though the interviewees did not use the term fantasy, it was clear how easily the sorts of descriptions offered lend themselves to such analysis. While the 'just a job' response evoked the fantasy of the unencumbered self for whom the job is merely a means to satisfy his or her real or true preferences, the 'alternative experience' reply tended to function as a stand-in for 
the beatific fantasy in which all hierarchy and conflict would be replaced with harmony, its correlative horrific fantasy being one of failure and cooptation by a form of capitalism or statism. In fact, they found that it was not so much the precise fantasmatic content that was key here as it was what I call the subject's investment in the fantasmatic content. Those subjects heavily invested in a fantasy - whether anticapitalist, ecological, or neoliberal in content - found it difficult to deal with contingency, recognize novelty, and thus could not feel at ease with experimenting with new ways of being. The over-enthusiastic anti-capitalist and cooperative idealist was found to be the one least able to stick it out when confronted with ambiguity and contingency since his/her overinvestment in the ideal would quickly shift into disillusion and a desire to flee.

Byrne and Healy point out how coops do not determine the mode of subjectivity of their workers (Byrne and Healy 2006: 253). It is simply not the case that only ethical subjects populate coops and ideological subjects populate capitalist firms or public institutions. Perhaps, however, one can make a weaker claim on account of the marginal status cooperative firms occupy at this particular historical conjuncture in a Western liberal-capitalist world. Those who opt out of the hegemonic capital-centric or state-centric forms of economic production and organization can no longer take the social and economic relations they engender for granted and must be open to new ways of thinking and organizing their work-life, let alone defending and promoting them. But the very form of a cooperative organization, by virtue of its tendency to promote democratic decision-making, also appears to demand a certain openness to contingency and to different ways of negotiating conflict. Contingency and conflict would seem to be much harder to avoid under these conditions and this tends to manifest itself in the explicit recognition on the part of cooperative subjects "that the productive, appropriative, or distributive processes of the firm are not given and may be transformed through struggle' (Byrne and Healy 2006: 252).

Byrne and Healy's qualitative research appears to suggest that evidence of this alternative ethos can be discerned in the ways worker-owners seek to extend the relevance and scope of their cooperative model, and in the ways they deal with concrete internal dilemmas regarding, for example, compensation for work that does not bear immediate fruit (eg., research and development). Such practices appear to show a collective commitment to addressing conflict and antagonism in the cooperative firm head-on. Interviewees tried to express what is involved in this headon confrontation with antagonism by saying they needed to be expressed rather than avoided, thus preventing their repression in the form of simmering feelings of resentment or their incorporation into heavily invested fantasies of exclusion and entitlement. Moreover, cooperative workers in the cases examined tended not to experience the legal, social, and other norms comprising the wider context within which the cooperative firm must operate 'as a Law to be obeyed or transgressed', nor did they invest their decisions and chosen courses of action with secretly wished-for guarantees that could easily lead to disillusion (Byrne and Healy 2006: 250-2).

Byrne and Healy do not in my view consider in detail the inter-relation between the ideological and politico-normative aspects of workplace practices. The value of their case analysis resides first, in the connection they make between fantasmatic enjoyment on the one hand and the subjects' aversion to ambiguity on the other hand, and second, in the glimpses they offer of an alternative post-fantasmatic mode of 
subjectivity. My interpretation of their work allows me to suggest that their initial findings add further support to the notion that a key component of the logic of fantasy is the subject's attachment to fantasy. To put it in other terms, the greater the fantasmatic attachment, the stronger the ideological grip. Thus, fantasmatic logics are understood to be operative when a subject is over-invested in a fantasy, so that anything which destabilizes or hints at destabilizing a subject's fantasmatic narrative, is experienced as a threat and provokes anxiety. The claim here is that overinvestment in fantasy structures the subject's enjoyment in a way I have described as ideological.

Byrne and Healy's empirical research on cooperative forms of organization suggests that perhaps a different sort of relation to fantasy - and thus mode of enjoyment or subjectivity - is possible, which one can qualify, following Lacan, as ethical. This way of approaching the political economy of workplace practices, then, has the potential to simultaneously pluralize and deepen the significance of the ways we think innovatively about the economy and its relation to the wider community. ${ }^{10}$ While overinvestment can help us understand why and how social structures are difficult to change, it can also help us understand the way in which social and political change does take place. In the following section I draw out the ideological and political implications of the logic of fantasy for the way we think about social and political transformation.

\section{Forms of Transformation, Modes of Enjoyment}

In this final section I extract, formalize, and generalize some key observations linked to the question of transformation in a way which can be made relevant to contexts beyond the workplace. In light of the above analyses, transformation can be characterized under two aspects, which it may be helpful to separate out analytically. First, transformation can be understood to take place at the level of socio-political reality: are the dominant norms governing a practice contested in the name of a new set of norms or not? Second, transformation can be understood to take place at the level of the subject's relation to those norms through the intermediaries of fantasy and mode of enjoyment. ${ }^{11}$ Separating out these two levels generates a two-by-two matrix which is spelled out in Table 1. Depending on whether norms are contested or whether there is a change in the mode of enjoyment, transformation is indexed by the movement from one cell to another.

\begin{tabular}{|l|l|l|l|}
\hline \multirow{2}{*}{$\begin{array}{l}\text { Level at which } \\
\text { transformation takes } \\
\text { place }\end{array}$} & \multicolumn{2}{|l|}{ socio-political reality (norms) } \\
\cline { 3 - 4 } & Social & Political \\
\hline $\begin{array}{l}\text { Mode of } \\
\text { Enjoyment }\end{array}$ & Ideological & $\mathrm{A}$ & $\mathrm{D}$ \\
\cline { 2 - 4 } & Ethical & $\mathrm{B}$ & $\mathrm{C}$ \\
\hline
\end{tabular}

Table 1

In Table 1, cell A represents the 'zero' level of a practice which I characterize as deeply sedimented because routine and ideological closure predominate. This does not mean, of course, that we have pure repetition. For example, educational practices vary from year to year, month to month, week to week, and day to day. At the level of 
content even the most rigid teaching session is never the same twice over, even if the norms governing this potentially infinite variety are considered to have remained unchanged. Avoiding the injunction 'don' $t$ ' in nursery care practices, avoiding the use of physical punishment as a way of disciplining primary school children, or treating university students as consumers, are all norms that partly make up a regime of educational practices. These norms can, of course, be executed in a wide range of ways, but in so far as they are not contested, there is little chance for transformation at the socio-political level. Likewise, insofar as elements of these practices are compatible with teachers' and parents' high investment in fantasies about children (their autonomy and wishes, their innocence and vulnerabilities, their well-being, their potential, and so on), there is also little chance for transforming this mode of enjoyment.

Yet, it is possible that subjects' relation to fantasy remains stuck in the mode of overinvestment, even as transformations take place at the level of fantasmatic content and/or socio-political norms $(\mathrm{A} \rightarrow \mathrm{D})$. For example, an overinvestment in fantasies about children's vulnerabilities may drive fears about their health, furnishing a political movement with the motivation and energy to change the norms of culinary practice in schools (involving, for example, the stipulation that all food must be healthy in a context of increased budgetary allowances). Conversely, it is possible to imagine a case in which the subjects' mode of enjoyment shifts in a way which does not disturb the continued appeal to existing social norms $(A \rightarrow B)$. Innovative experimentation with healthier food sources or with cooking and presentational aspects of school culinary practice may meet with approval or not. It may (though need not) result in healthier dishes within existing budgetary and normative constraints. But though the norms of culinary practice may remain unchanged, the subjects engaged in it are more attuned to the contingency and creative potential of social reality. Finally, one can also imagine a situation in which the shift in one's mode of enjoyment is accompanied by the public contestation and transformation of social norms $(A \rightarrow C)$. When a newfound sensitivity to the contingency and creative potential of social reality undergirds a political project aiming to transform the norms of culinary practices in schools as a whole (ie., a regime of school culinary practices), we could say that transformation takes place at both levels.

What is common between cells A and D is the subject's overinvestment in a fantasmatic narrative, whether this fantasy sustains existing social norms by keeping public contestation at bay (cell A) or whether it sustains the drive to replace these social norms with a new set of norms, thus bringing the political dimension to the fore (cell D). It is the mode of enjoyment related to such overinvestment in fantasy that I link to the ideological dimension of social relations. But even though political mobilization may often succeed because its ideological inflection provides powerful motivational energy, my analysis of Byrne and Healy's discussion shows us that fantasmatic over-investment carries its own dangers. Such overinvestment often leads to disappointment and desertion because the outcome of such struggles rarely, if ever, measures up to one's (fantasmatic) expectations. It raises the question of whether political mobilization and struggle, wherein subjects bear a different relation to fantasy, is not more likely to be long-standing, dynamic, and innovative (cell C). This is because the subject has here already taken some distance from its fantasy and the sorts of guarantees that accompany fantasmatic overinvestment. Genuine openness to contingency becomes possible in this case, something which Zizek associates with 
true materialism (Zizek 2002: lii) and Connolly with the ethos of pluralization and deep pluralism (Connolly 1995, 2005). Whereas the conception of transformation implied in the movement $\mathrm{A} \rightarrow \mathrm{D}$ often entails a struggle between competing fantasies, the conception of transformation implied in the movement $A \rightarrow B$ and $A \rightarrow C$ entails primarily a struggle with fantasy, yielding a potentially different relation to it.

Whether this latter conception of transformation is discussed in the context of political theory generally or political economy more specifically, my exploration suggests that with detachment from (rather than abandonment of) fantasy comes the possibility of realizing the potential for political resignification. Wendy Brown's discussion of 'wounded attachments' (Brown 1996: Ch. 2) can be said to speak precisely to the dangers of fantasmatic overinvestment. Brown worries that making past and present injury the basis of political demands often ends up reinforcing one's psychic attachment to this injury as well as reinscribing the conditions which make such injury possible. The claim here is that the enjoyment procured in 'reliving a certain punishing recognition reassures us not only of our own place (identity) but also of the presence of the order out of which that identity was forged and to which we remain perversely beholden' (Brown 2001: 56). It is easy to underestimate the debilitating effects of ressentiment and guilt associated with the thought that others are responsible for the theft of our enjoyment. If so, we can hypothesize that the enjoyment associated with our investment in fantasies of victimization and rescue constrains the possibility of transformation. For this one requires a different mode of enjoyment and relation to fantasy, something which 'might take shape as a certain ironic ethos or as a spirit of radical, critical patriotism - or it might take some other form, as yet unthought' (Brown 2001: 59).

In light of my earlier analysis, this suggests that there is a mode of enjoyment associated with closure and a mode of enjoyment associated with openness. While the former has a 'logic', more specifically a fantasmatic logic, which grips through transgression and guilt, the latter escapes attempts at capture - indeed, it appears to entail the dissolution of such a logic. Instead, it is characterized by an alternative ethos which signals a commitment to recognizing and exploring the possibilities of the new in contingent encounters. If the former can be linked to an ideological mode of being, then we could say that the fidelity to contingency can be linked to an ethical mode of being.

\section{Conclusion}

In this paper I engage with a small but significant literature at the intersection of Lacanian psychoanalysis, poststructural political theory, and the political economy of workplace practices. I have sought to build upon this literature by drawing out the ideological and political implications of taking seriously what I call the logic of fantasy. More specifically, I reinterpret and resituate existing case material to illustrate this logic and to draw out implications for the way fantasies sustain workplace practices. I make explicit two modes of enjoyment in relation to the political economy of workplace practices, and the kinds of transformation that these make thinkable for practices in general. In this view, fantasy may help us better understand not just the process by which a particular configuration of political economy is sustained, but also the process by which support is galvanized for political mobilization and the contestation of existing practices. This suggests that the public 
contestation of norms and mobilization of struggles through various political logics can be just as ideological as those forces which exploit fantasmatic elements to maintain the status quo. What sorts of questions does this way of thinking open up, then $?^{12}$

There is a general consensus in the literature that the mode of enjoyment associated with an ethics of openness is to be preferred, especially when thinking critically about the political economy in general and about contemplating the transformation of the political economy of workplace practices in particular. What receives much less attention in this literature, however, are the conditions under which such a transition from one to another mode of enjoyment may be effected in practice. More modestly, it raises questions about the conditions under which the content of a fantasmatic narrative may shift and the nature of the sorts of intervention that they make plausible. It also raises questions about how these conditions of transformation (of fantasmatic content and/or mode of enjoyment) vary as a function of institutional setting (private, public, cooperative, voluntary, charitable, etc.)? Should such conditions be thought in terms of subjective and/or structural features, for example? Earlier, it was noted how an ethical relation to workplace practices entails risking the loss of one's identity and moving away from trying to capture a lost or new paradise. In light of Wendy Brown's critical remarks, it will be important that analysts considering questions of intervention make sure that this insight takes into account, rather than displaces or ignores, the obvious fact that many subjects articulate their demands in narratives of injury. Under what conditions, for example, might grievances and resentments be articulated in ways that do not succumb to ressentiment and the temptations of scapegoating?

The analytical distinction between the level of socio-political reality and mode of enjoyment correlates roughly with the distinction between the normative and ethical dimensions of critique. And this opens up a related set of critical, methodological, and political questions. For example, to what degree is it possible to sustain the distinction between ethical and normative considerations in one's critical analyses? Does not ethical critique imply a normative commitment of sorts, and/or vice versa? If so, how precisely, and with what methodological and empirical implications? The distinction also raises tricky methodological questions about how best to ascertain or grasp innovatively when subjects are (ideologically) attached to their fantasy; or, conversely, when they are (ethically) detached from their fantasy. It also suggests a need to make explicit the normative framework presupposed by the analyst, even if this framework ought to be seen as strongly and dynamically inflected by the specificity of the case being analysed. From the point of view of a critical political economy, this normative dimension can be linked to processes of production, appropriation, and distribution, wherein the appropriation by others of workers' surplus wealth is considered prima facie exploitative. (From this perspective capitalist and state-centric forms of organization are equally exploitative.) In this view, fantasy may help us better understand the processes by which a particular configuration of political economy is sustained, because its logic can tell us something about the ideology of work, and thus about how it may be possible to transform existing social logics of production, appropriation and distribution.

This, in turn, suggests the need to investigate in more empirical and ethnographic detail the relation between fantasies and the normative dimension of a practice; the 
relation between fantasies and the ethical dimension of a practice; and the dynamic interaction between these two sets of relations. More specifically, it suggests that studies need to be sensitive to the context-specificity of cases, subjects' selfinterpretations inclusive, so that critical evaluations are not too 'external' and heavy handed, and thus of limited value from the point of view of effective critique and transformative potential. This means that the social norms and logics of workplace practices need to be clearly delimited or described, so that the implications of the analysis for thinking differently about processes of production, appropriation, and distribution, can be developed to their full potential.

The discussion of counter-logics and the role of judgement is important in this context. The opportunity and political significance of resignification is central to this account, as we saw in the opening section. For it calls for an attentiveness to the new or surprising, and to invest in them imaginatively by articulating this novelty in a way which identifies, preserves, and enhances their critical and transformative potential. So while it may be true that specific cooperatively organized workplace practices, for example, may be judged as failing to materialize an alternative 'non-' or 'post-' fantasmatic mode of enjoyment and subjectivity, or may be judged as having been coopted by capitalist or statist models, there will also be instances in which their status is much more ambiguous. In these latter cases it may be appropriate and indeed critical to judge them as having a 'fugitive energy' that can be given an ethical or normative resignification. It may be resignified in a way that exemplifies a different relation to fantasy and thus a different mode of enjoyment, and/or in a way that projects a different normative valence. The role of the analyst's judgement becomes crucial in these cases, because no sooner are alternate modes of subjectivity and counter-logics identified, than they provide conditions for possible political mobilization.

\section{References}

Best, M. H. and Connolly, W. E. (1982) The Politicized Economy, Lexington, Massachusetts: D. C. Heath and Co.

Brown, A. D. and Humphreys, M. (2006) 'Organizational Identity and Place', Journal of Management Studies, 43(2): 231-57.

Brown, W. (1996) States of Injury, Princeton: Princeton University Press.

Brown, W. (2001) Politics out of History, Princeton: Princeton University Press.

Byrne, K. and Healy, S. (2006) 'Cooperative Subjects', Rethinking Marxism, 18(2): 241-258.

Connolly, W. (1995) The Ethos of Pluralization, Minneapolis: University of Minnesota Press.

Connolly, W. (1999) Why I am Not a Secularist, Minneapolis: University of Minnesota Press.

Connolly, W. (2002) Neuropolitics, Minneapolis: University of Minnesota Press.

Connolly, W. (2005) Pluralism, Durham: Duke University Press.

Contu, A. and Willmott, H. (2006) 'Studying Practice', Organization Studies, 27(12): 1769-1782.

Copjec, J. (1994) Read My Desire, Cambridge, MA: MIT Press.

Daly, G. (1999) 'Ideology and its Paradoxes: Dimensions of Fantasy and Enjoyment', Journal of Political Ideologies, 4(2): 219-38.

Daly, G. (2004) 'Radical(1)y Political Economy', Review of International Political Economy, 11(1): 132.

Dean, J. (2008) 'Feminist Purism and the Question of 'Radicality' in Contemporary Political Theory', Contemporary Political Theory, forthcoming.

Freeden, M. (2005) 'What Should the 'Political" in Political Theory Explore?', The Journal of Political Philosophy, 13(2): 113-34.

Fleming, P. and Spicer, A. (2007) Contesting the Corporation, Cambridge: CUP. 
Gabriel, Y. (1995) 'The Unmanaged Organization: Stories, Fantasies and Subjectivity', Organization Studies, 16: 477-501.

Gabriel, Y. (1997) 'Meeting God: When Organizational Members Come Face to Face with the Supreme Leader', Human Relations, 50(4): 315-342.

Gibson-Graham, J. K. (2006) A Postcapitalist Politics, Minneapolis: University of Minnesota Press.

Glynos, J. (2001a) 'The Grip of Ideology: A Lacanian Approach to the Theory of Ideology', Journal of Political Ideologies, 6(2): 191-214.

Glynos, J. (2001b) 'There is no Other of the Other: Symptoms of a Decline in Symbolic Faith', Paragraph, 24(2): 78-110.

Glynos, J. (2003) 'Self-Transgression and Freedom', Critical Review of International Social and Political Philosophy 6(2): 1-20.

Glynos, J. (2008) 'Self-Transgressive Enjoyment as a Freedom Fetter' Political Studies, 56(3), forthcoming.

Glynos, J. and Howarth, D. (2007) Logics of Critical Explanation in Social and Political Theory, Abingdon: Routledge.

Glynos, J. and Stavrakakis, Y. (2008) 'Lacan and Political Subjectivity' Subjectivity: International Journal of Critical Psychology, 24, forthcoming.

Knights, D. and Willmott, H. (eds) (1990) Labour Process Theory, London: Macmillan.

Laclau, E. (1990) New Reflections on the Revolution of Our Time, London: Verso.

Laclau, E. (1991) 'The Impossibility of Society', Canadian Journal of Political and Social Science, 15(1/3): 24-7.

Laclau, E. (2005) On Populist Reason, London: Verso.

Laclau, E. and Mouffe, C. (1985) Hegemony and Socialist Strategy, London: Verso.

Madra, Y. M. (2006) 'Questions of Communism', Rethinking Marxism, 18(2): 205-224.

O'Doherty, D. and Willmott, H. (2001) 'Debating Labour Process Theory: The Issue of Subjectivity and the Relevance of Poststructuralism', Sociology, 35(2): 457-476.

Orr, J. E. (1996) Talking about Machines, Ithaca: Cornell University Press.

Ozselcuk, C. (2006) 'Mourning, Melancholy, and the Politics of Class Transformation', Rethinking Marxism, 18(2): 225-240.

Ozselcuk, C. and Madra, Y. M. (2005) 'Psychoanalysis and Marxism', Psychoanalysis, Culture \& Society, 10: 79-97.

Resnick, S. and Wolff, R. (1987) Knowledge and Class: A Marxian Critique of Political Economy, Chicago: University of Chicago Press.

Resnick, S. and Wolff, R. (2005) 'The Point and Purpose of Marx's Notion of Class', Rethinking Marxism, 17(1): 33-7.

Sennett, R. and Cobb, J. (1977) The Hidden Injuries of Class, Cambridge: CUP.

Sennett, R. (1998) The Corrosion of Character, New York: Norton.

Stavrakakis, Y. (1999) Lacan \& the Political, London: Routledge.

Walkerdine, V. (2005) 'Freedom, Psychology and the Neoliberal Worker', Soundings, 29: 47-61.

Walkerdine, V. (2006) 'Workers in the New Economy: Transformation as Border Crossing', Ethos, 34(1): 10-41.

Willmott, H. (2007) 'Identities in Organizations', unpublished.

Zizek, S. (1989) The Sublime Object of Ideology, London: Verso.

Zizek, S. (1994) The Metastases of Enjoyment. London: Verso.

Zizek, S. (2002) For They Know Not What They Do. London: Verso.

Zupancic, A. (2000) Ethics of the Real, London: Verso.

\section{Notes}

${ }^{1}$ This paper will appear as an article in the October 2008 issue of the Journal of Political Ideologies. Versions of this paper were presented at the Essex Political Theory group forum and at the Annual Political Studies Association Conference, Swansea University, 1-3 April 2008. For their questions and feedback I thank Pete Bloom, Carl Cederstrom, Sam Chambers, Glyn Daly, Derek Hook, David Howarth, Dave Lewis, Aletta Norval, Yannis Stavrakakis, Albert Weale, and Hugh Willmott.

${ }^{2}$ This paper will appear as an article in the October 2008 issue of the Journal of Political Ideologies. Versions of this paper were presented at the Essex Political Theory group forum and at the Annual 
Political Studies Association Conference, Swansea University, 1-3 April 2008. For their questions and feedback I thank Pete Bloom, Carl Cederstrom, Sam Chambers, Glyn Daly, Derek Hook, David Howarth, Dave Lewis, Aletta Norval, Yannis Stavrakakis, Albert Weale, and Hugh Willmott.

${ }^{3}$ The focus on workplace practices of course suggests that this contribution would also be relevant to the literature that engages directly or indirectly with the debates around labour process theory and critical management studies (eg., Knights and Willmott 1990; O'Doherty and Willmott 2001; Fleming and Spicer 2007; Sennett and Cobb 1977; Sennett 1998).

${ }^{4}$ For more on how ideology and ethics are understood in this article, see Glynos \& Howarth 2007: 117120.

${ }^{5}$ The place and role of norms in practices will be further developed in the article in terms of a distinction between the social and political dimensions of a practice.

${ }^{6}$ In a similar way, Michael Freeden views practices as animated by 'the inevitable tension between the desire for decontestation [or closure] and its impossibility' (Freeden 2005: 123).

${ }^{7}$ Political logics can be seen, following Laclau and Mouffe, to comprise logics of equivalence and logics of difference. For more detail on this, see Glynos \& Howarth 2007: 141-145; Laclau \& Mouffe 1985: 127-134).

${ }^{8}$ Of course counter-hegemonic reinterpretations do not by any means necessarily embody progressive values, but it is precisely because of this that analysts cannot ignore the normative valence of their analyses. (For more detail on the question of judgement and naming see Glynos \& Howarth 2007: 183187.) The very identification and articulation of social logics and counter-logics thus furnish both elements and an initial direction which can form part of a more concerted political project. (For some illustrative suggestions regarding diagnoses and ways forward, see Best and Connolly 1982: 71-5, 1018, 117-47, 208-215, 219-20, 226-9.)

${ }^{9}$ On the notion of individual and collective self-transgression, especially in relation to classical analyses of the concept of freedom, see Glynos 2003, 2008.

${ }^{10}$ In appreciating the character of the distinction between two modes of enjoyment or subjectivity, it is worth recalling that overinvestment in fantasies is perfectly compatible with social and political transformation. Such overinvestment can manifest itself in the 'purity' of the ideals espoused by radical groups. In my reading, the work of Jonathan Dean, for example, shows how such overinvestment has played a role not only in the political transformations brought about by radical feminist groups, but also in sustaining the characterization of contemporary feminism as deradicalized, because it is felt that in building links with state and other public institutions many feminist organizations have been 'contaminated' by patriarchal social logics (Dean 2008).

${ }^{11}$ Fantasy serves to mediate between the two levels because it comprises elements of socio-political reality which organize the subject's enjoyment, thereby also serving to shape that socio-political reality.

${ }^{12}$ See also Glynos and Stavrakakis 2008. 